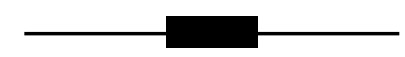

\title{
Introduction
}

\section{Human-Animal Relations}

\section{Rebecca Feinberg, Patrick Nason, and Hamsini Sridharan}

In studying the lives and livelihoods of human beings, the social sciences and humanities often find their lines of inquiry tugged in the direction of other, nonhuman beings. When Claude Lévi-Strauss (1963) suggested that "thinking with" animals was relevant and fruitful to the study of humankind, scholars began to follow these leads with academic rigor, enthusiasm, and creativity. Propelled into the new millennium by the passion of the environmental movement, compounded by natural and anthropogenic disaster, and now entrenched in the discourse of the Anthropocene, recent scholarship has simultaneously called into question the validity of human exceptionalism and expanded our social and political worlds to include animals and myriad other nonhuman beings. This move is paradoxical: as the significance of human action on this planet has increased, the category of the human is continually challenged and redrawn. While contemporary posthumanist critique rethinks the importance of animals and strives to destabilize long-standing ontological exceptions, it does so just as the effects of human presence overwhelmingly single out our species as the dominant agents of planetary change (see Chakrabarty 2009; Steffen, Crutzen, and McNeill 2007).

As we question what it means to be (and to be called) "human," so too we must question what it means to be considered "animal." There are many forms of life-plants and microbes, for example-which are not included in Kingdom Animalia, yet are of interest to scholars in this issue. We use "human-animal relations" in reference to a growing body of work that explores interactions within Animalia, including moments that challenge the animal as an established category.

To situate this scholarship in a critical historical context, we find it useful to loosely organize the study of human-animal relations into two emergent techniques that attempt to challenge the species barrier while simultaneously calling into question the worldly consequences of a conceptual reorganization. We then direct our attention to the authors of the articles in this issue as they examine the questions that arise as other forms of being come to be represented in ways both new and old.

The first technique used in the contemporary study of human-animal relations concerns ontologies and subjectivities. It suggests that the exclusive study of humanity yields only internal insights: patterns of significance and meaning among our species alone. While the concept of the animal has long offered the ultimate Other against which to define the boundaries of the human, this binary is just one of the many ways humans and animals shape one another's existences and experiences of the world. Whether ethnographic, ecological, or philosophical, the authors cited throughout this issue bring a web of relations into focus, transversing species 
lines in conversations across the disciplines. The productive tension that excites so many of us (humans, at least) when speaking of animals finds its place amid this web-in the teeming points of contact between primates, birds, pigs, elephants, trees, mushrooms, bacteria, viruses, and other flora, fauna, and fungi.

Some of the most provocative of these works inhabit the world of multispecies ethnography (Kirksey and Helmreich 2010). Heeding the call of Deleuze and Guattari (1987), Haraway (2003, 2008), and Latour $(2002,2004)$ among others, scholars following this intriguing dialogue aim to restructure the grand narrative of being, moving away from fixed, rigid structures toward fluid, interactive multiplicities. Their research extends the theoretical and methodological domain of anthropology and the humanities to the study of nonhuman beings, attending to the significance of animal presences, histories, and futures. By studying diverse forms of life in their pairings, possessions, and pathologies, scholars of multispecies ethnography speak new ideas and new terminologies that complicate the concept of the human.

While potentially inspirational, this biocentric worldview and its epistemological commitments are inherently problematic. As the selective practices of inclusion, exclusion, and organization are questioned, and the conceptual boundary between the human and the animal is weakened, we must ask ourselves: In what sort of world does this leave us? In what capacity can, or should we act? For social scientists, these questions evoke many of the ethical dilemmas concerning identity, agency, and representation characteristic of postcolonial critique.

The second technique taken up in this scholarship is not only critical of human exceptionalism, but also attempts to describe and predict who wins and loses at its moments of subversion. This ethico-political lens scrutinizes the techniques and motivations by which certain humans structure the existences of certain other beings. The literature from conservationists and social theorists alike describes a vital power over life and death to be exercised and contested by more or less responsible human stewards. As we seek to come to a more responsible or more equitable ethics of "living with" the natural world (Kirksey and Helmreich 2010), an understanding of how such relations of power reflect and intersect with interhuman politics demands that we consider questions of biopolitics, belonging, alienation, and the political ecology of humananimal dominance.

Whatever their approach, human-animal scholars are tasked with describing a world in which humans do not automatically take precedence over other beings. This must be done without ignoring the dynamic and often conflicting patterns of social interaction among coexistent forms of life. Asymmetries of power are reflected by asymmetries of imagination. With this in mind, the authors in this issue introduce, review, and critique research spanning multiple disciplines, ontologies, and epistemologies.

Laura Ogden, Billy Hall, and Kimiko Tanita define and characterize multispecies ethnography by placing it in the broader context of conversations in philosophy, the biosciences, animal rights activism, and human geography. They observe that multispecies ethnography is philosophically anti-essentialist, and requires a decentering of the human and recognition of the coproduction and hybridity of the social and the natural. Moreover, it demands a reconsideration of the notion of species itself, and the human-as-species, while paying increased attention to asymmetries of power in the politics of "Animals, Plants, People, and Things." Ultimately, the authors compellingly argue, one of the greatest strengths of multispecies ethnography is the "speculative wonder" captured in its ontological revisions, a wonder rife with potential to generate alternative ethical possibilities for living in the world.

Katherina Schneider brings a rich body of Melanesian ethnography into the multispecies conversation, diverging from Western theories of the subject by suggesting gender and exchange as mechanisms of crossing. To think of living or nonliving objects as "agents, causes, contain- 
ers, or substances" through which amorphous sets of social relations are rendered intelligible provides one pathway to a posthuman theory of being, where ways and forms of existence are better explained as circulations, transformations, and iterations of sociality.

Wherever we humans go, we seem to carry plants and animals with us. Crystal Fortwangler opens an interdisciplinary discussion of these human-mediated species introductions by reviewing scholarship from the social sciences, ecological sciences, and humanities. In order to define the debate and identify potential points of agreement, she compares the shifting disciplinary approaches to thinking about whether and how introduced species are framed as problematic (as "invasive species," for instance), and how we decide what is to be done with them (kill them, coexist with them, and everything in between). In doing so, her article points to how introduced species serve as a focal point in an increasingly multi- and interdisciplinary conversation about human and nonhuman belonging-in-place, one that can be richly illustrated through multispecies storytelling.

Focusing on what he calls "animal inclusive diseases," Alex Nading draws us into the world of animals and insects that host viruses, bacteria, and fungi, suffer illness, and infect humans. $\mathrm{He}$ traces the historical turn toward medical questions in human-animal studies and examines the practices of applied disease ecology, before turning to the perspectives that biosecurity has to offer, and suggesting an approach to health that emphasizes interspecies entanglements. Looking at how humans and nonhumans-a category which, Nading reminds us, includes not just animals, but the microscopic inhabitants of internal microbiomes-interact and share in disease and suffering offers the potential for not only shaping more inclusive policy, but also recognizing such dynamic entanglements in domains beyond health.

Next, Piers Locke channels posthumanist and biocultural perspectives in his introduction of the particular interspecies discursive space he calls "ethnoelephantology." Embracing principles of history, ethnography, and ecology, Locke moves across disciplines and beyond restrictive materialities to set a productive course for human-elephant studies. As elephants and their human counterparts are increasingly caught up in resource conflicts, this marks one set of opportunities for conservationists to weigh their methods of animal protection, stewardship, and management against multispecies ideas of coexistence.

While the symbolic value of certain species has long been cultivated by conservation organizations, the strategic deployment of this value can exacerbate or even create socioecological conflicts. In their article "Flagships or Battleships," Leo Douglas and Diogo Verissimo review the mechanisms through which the "multivocality and arbitrariness" of symbols complicates their systemic use. As the physical significance of animals varies between individuals and communities, so too does their symbolic value. If they are good to think with, animals are thought with in many different ways by different groups of people. A qualitative approach to conservation research might indicate these metaphysical differences before they manifest as ecosystemic battles.

Erica Hill identifies the emergence of "a prehistory of human-animal relations" that eclipses previous utilitarian perspectives. By inviting questions of personhood and agency into the analysis of animal burial sites, she asks what a social zooarcheology might look like and considers the methods by which it can reconstruct not only human-animal sociality, but animal individuality and subjectivity. Hill is wise to acknowledge the variability inherent to studies of relationality, whether in the past or the present. Like their living descendants, the remains of animals do not speak. Thus, the study of animal agency remains partial to the unspoken-the spiritual, the aesthetic, affective-and their material representations in animal remains and structured deposits.

Finally, building on historical lessons to consider the future, Danielle DiNovelli-Lang challenges the integrity of posthumanist critique by questioning how a move beyond the nature- 
culture divide in anthropological representations of nonhuman others encounters pervasive and historically dangerous distinctions between indigeneity and modernity. From Amazonia to Alaska and through readings of Heidegger, Uexküll, Ingold, and Latour, she rightfully dredges up the "cold, dark truths" of ontological relativism that multispecies theory must address if it is to continue its momentum and simultaneously uphold the standards of justice for indigenous others.

As our particular species grows increasingly and alarmingly aware of its power to shape life on Earth, our very particularity is called into question. Both critically and constructively, humananimal scholars have focused their attention on interspecies relations as they manifest in various forms of ecological companionship and conflict. To consider a social world composed of diverse relationships between millions of energy-consuming, material bodies is proving to be more fruitful than upholding the stubborn dichotomies of the past. At the same time, lessons from the past are crucial to an ethical path forward. To represent entangled ways of being in intelligible and conscientious ways, the authors here write toward messy multiplicities in order to identify the worldly potentialities of a posthuman philosophy.

Of these lessons, the important debates over issues of power and representation have pushed the social sciences and humanities to refine and expand their perspectives. The so-called multispecies turn finds itself at once critical of former injustices and in dangerous proximity to them. As this new approach to human-animal relations conceptualizes new ways of being and interacting, it risks losing sight of the fact that even in a biocentric web of relations, questions of power are inherent to acts of representation. How might we write about politics and power at the level of animal Others when the author's own ontological position is essentially authoritative? If the animal is or has become political, it remains for the moment without a voice. As the articles in this issue suggest, ethical human-animal scholars cannot simply erase the borders between species and expect the living beings placed within those categories to run free, proliferate, and prosper. With this in mind, we direct our attention to the ways human scholars are, very carefully, thinking with animals.

\section{REFERENCES}

Chakrabarty, Dipesh. 2009. “The Climate of History: Four Theses.” Critical Inquiry 35, no. 2: 197-222.

Deleuze, Gilles, and Pierre Félix Guattari. 1987. A Thousand Plateaus: Capitalism and Schizophrenia. Vol. 2. Minneapolis: University of Minnesota Press.

Haraway, Donna. 2003. The Companion Species Manifesto: Dogs, People, and Significant Otherness. Chicago: Prickly Paradigm.

Haraway, Donna. 2008. When Species Meet. Vol. 3. Minneapolis: University of Minnesota Press.

Kirksey, S. Eben, and Stefan Helmreich. 2010. “The Emergence of Multispecies Ethnography." Cultural Anthropology 25, no. 4: 545-76.

Latour, Bruno. 2002. War of the Worlds: What about Peace? Chicago: Prickly Paradigm.

Latour, Bruno. 2004. Politics of Nature. Cambridge, MA: Harvard University Press.

Lévi-Strauss, Claude. 1963. Totemism. Trans. R. Needham. Boston: Beacon Press.

Steffen, Will, Paul J. Crutzen, and John R. McNeill. 2007. "The Anthropocene: Are Humans Now Overwhelming the Great Forces of Nature." Ambio: A Journal of the Human Environment 36, no. 8: 614-21. 